\title{
EDITORIAL
}

\section{EDUCAÇÃO CONTINUADA EM CIRURGIA}

\author{
Aldo da Cunha Medeiros, TCBC
}

A Educação Médica Continuada (EMC) permanece representando um problema antigo, com necessidade de disponibilidade de longo tempo dos médicos de todas as áreas, mormente dos cirurgiões. No âmbito das Universidades Brasileiras, às quais caberia a iniciativa pela educação continuada, observa-se que, salvo raras exceções, dedicam-se à pósgraduação e à pesquisa, em detrimento da graduação e de cursos de extensão, muitas delas alheias às grandes mudanças sociais e econômicas mais recentes. Esquecem que existe uma grande demanda na área de prestação de serviços, em especial sob a forma de educação continuada. Com a percepção do problema, têm atuado as associações de classes e colégios de especialistas, como o Colégio Brasileiro de Cirurgiões.

É preciso que se dê atenção a um contingente expressivo de colegas profissionais em todos os Capítulos desse imenso país, muitos deles à margem das novas conquistas na área do conhecimento de cada especialidade cirúrgica. Há muitos executando trabalho repetitivo e desatualizado, sem estímulo para o crescimento na carreira, relutando na busca do conhecimento ou mesmo sem a autopercepção de falhas que possam estar cometendo na clínica. Torna-se evidente que um dos determinantes fundamentais para que tal esteja ocorrendo é a falta de motivação. Observa-se, em primeiro lugar, que quase não há oferta sistemática de bons programas institucionais de educação continuada na área cirúrgica. Em segundo lugar, não tem havido exigência desta atividade por parte das instituições empregadoras, que deveriam fazê-lo, inclusive oferecendo condições, incentivos e progressão funcional para os que participassem de programas dessa natureza. Sem dúvida, todos ganhariam em competência, atenção aos doentes e melhoria na resolução dos problemas cirúrgicos, ao mesmo tempo em que abriria um canal para troca permanente de informações sob a forma de um sistema de referência. Nos serviços onde há programas de educação continuada em Medicina, tem ocorrido intensa e salutar troca de experiências e tira-dúvidas entre as instituições promotoras dos cursos e sua clientela. Mantém-se, portanto, um vinculo de atualização, de indagações e de solução de problemas.

A propósito, está em discussão no Conselho Federal de Medicina, proposta de obrigatoriedade do exame de qualificação para todos os médicos recém-formados antes de iniciarem o exercício da Medicina, à semelhança do que existe na Ordem dos Advogados do Brasil. Seria altamente salutar e oportuna a discussão da institucionalização de programa de EMC semelhante ao CME (Continual Medical Education), rigorosamente funcionando nos Estados Unidos da América há muitos anos. A abertura de grande número de novas Escolas de Medicina nos últimos tempos e a formação precária de um número exagerado de médicos, fazem parecer que haja, não uma necessidade de médicos, mas um promissor e rentável mercado de estudantes de Medicina, e clamam por discussões e providências como estas.

Percebe-se que a legislação brasileira a respeito do exercício da Medicina é muito antiga, permitindo ao recém-formado exercer a profissão com ou sem a formação adequada, em qualquer especialidade. Os riscos em potencial são enormes, motivos de exposição da profissão como um todo aos escândalos de erros médicos na mídia de modo sistemático e implacável. Em muitos casos a ausência de programa sério de EMC com acompanhamento de desempenho sob a forma de créditos ou outro critério eficaz privilegia o ócio e a ignorância, com repercussões danosas no padrão da assistência médica.

A gritante necessidade de mudança nesse aspecto da maior importância deveria mobilizar instituições como o Colégio Brasileiro de Cirurgiões, Associação Médica Brasileira, Ministérios da Educação e da Saúde, Academia Nacional de Medicina, Conselho Federal de Medicina e outras para: 1. Colocarem o problema em discussão; 2 . Chegando ao consenso da implantação do sistema, investirem em infra-estrutura para criação de programa amplo de EMC com pedagogia e metodologia adequadas; 3 . Recrutarem serviços acreditados; 4 . Tomarem a EMC obrigatória como pré-requisito para a continuidade do exercício profissional e para a ascensão funcional. Todos ganhariam: o doente (principal), médicos, instituições, educadores e a sociedade como um todo. 